\title{
BREEDING RAPTOR CENSUS IN Grand Teton NATIONAL PARK, 2002
}

\author{
DEREK CRAIGHEAD $\downarrow$ ROGER SMITH \\ BERINGIA SOUTH $\uparrow \mathrm{KELLY} \uparrow \mathrm{WY}$
}

\begin{abstract}
$\downarrow$ AbSTRACT
We documented abundance and diversity of raptors in a relatively undisturbed landscape in Grand Teton National Park, Wyoming, from February through August 2002. Within a $31.1 \mathrm{~km}^{2}$ study area we located 46 nesting pairs that consisted of 9 raptor species. The American kestrel (Falco sparverius) and the Common raven (Corvus corax) were the two most abundant species on the study area. We considered Common ravens as an ecological and trophic level equivalent of raptors. Six of nine species fledged at least one young, and the mean number of young fledged per occupied nest for all species was $1.0(\mathrm{sd}=1.0$, range $=0$ to 3.0$)$. We observed complete nesting failure for Swainson's hawks $(n=4$ nests), Bald eagle ( $\mathrm{n}=1$ nest), and the Long-eared owl $(\mathrm{n}=1$ nest). We located the territory but not a nest for two Great horned owl (Bubo virginianus) adults, and two Sharp-shinned hawk adults. Six of the nine species observed in 2002 migrate, and two of the nine species are known neotropical migrants. Cold and wet weather conditions along with a high wind storm during the early incubation period appeared to have a negative effect on the breeding success of stick-nest breeders on the study area.
\end{abstract}

\section{$\downarrow \quad$ INTRODUCTION}

This report summarizes census efforts during 2002 for raptors on the Blacktail Butte study area, Grand Teton National Park (GTNP). We present data on abundance and diversity of raptors, level of search effort, and weather conditions during the breeding season. Raptor census data were recorded on this same site in 1947, 1975, and 1987, and 2001. Our objectives were to census the raptor population in the Blacktail Butte study area in 2002.

\section{$\downarrow \quad$ STUdy AREA}

The study area (Figure 1$)$ is a $31.1 \mathrm{~km}^{2}(12$ $\left.\mathrm{mi}^{2}\right)$ area located in northwestern Wyoming within GTNP (43 40N, $11043 \mathrm{~W})$. This study area was used in three previous raptor studies: 1947 (Craighead and Craighead 1956), 1975 (Craighead and Mindell 1981) and 1987 (Craighead et al. 1987). GTNP is situated in a high mountain valley that is surrounded by the Teton range to the west, the Gros Ventre mountains to the east, and the Yellowstone plateau to the north. Within the study area, vegetation, climate and landscape features have been described by Craighead and Craighead (1956), and Dunk et. al. (1997). Elevation of nests within the study area ranged from $1934 \mathrm{~m}$ to $2164 \mathrm{~m}$. Most of the non-forested area in the study area was in hay production until the mid 1960 's. Currently, $14.6 \mathrm{~km}^{2}$ (47\%) of the study area is timbered, and $16.5 \mathrm{~km}^{2}(53 \%)$ is open sage/shrubland and/or remnant agricultural area that consists mainly of non-native grass (Bromus spp.). Three human-development areas were present within the study area: 1) GTNP headquarters in Moose, Wyoming; 2) Dornan's village which consisted of a restaurant, store, outdoor restaurant, guest cabins, and several retail shops; and 3) the Murie center which consisted of administrative cabins, guest cabins, and established hiking trails. 


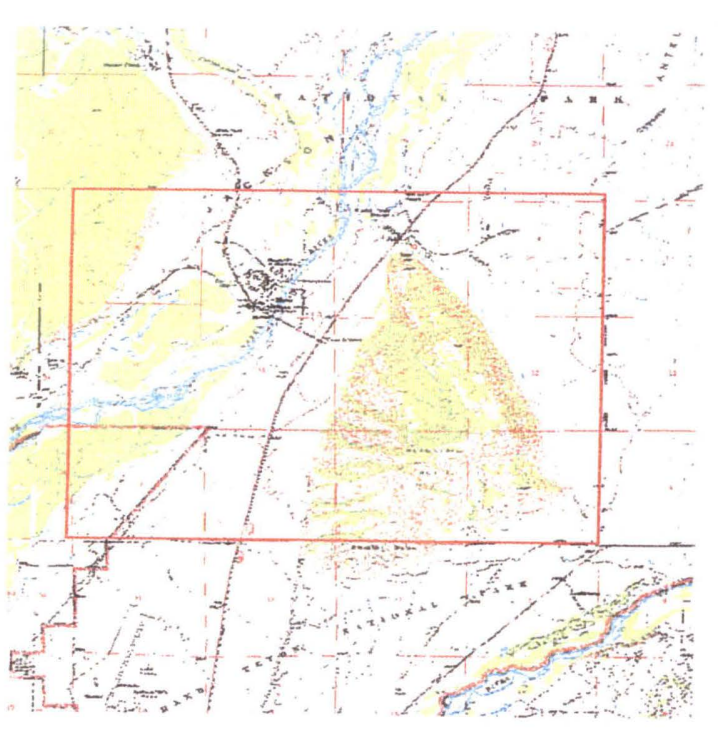

Figure 1. The 31.1 square kilometer study area ne Moose, Wyoming.

\section{$\diamond \quad$ METHODS}

Nesting census-We followed nestsearching methodology used in 1947 (Craighead and Craighead 1956). Our goal was to locate as many occupied nesting raptors as possible within the designated study area. From February through August, we repeatedly searched the study area. We re-visited all nesting territories occupied during 1947 , 1987 and 2001 census efforts. We did not have nest locations from the 1975 census. We considered a historical nesting area to be vacant if we detected no sign of occupancy by the end of the brood-rearing period. We conducted direct observations of nesting areas from a distance for nest-building activity, prey deliveries or other behaviors that would help pinpoint a nest. Duration of observation sessions ranged from two to eight hours. All bird movements during each observation session were recorded onto USGS 7.5 minute quadrangle maps. We surveyed for owl nesting areas during pre-dawn and late evening from late February-April to improve detection of nests.

To quantify the effectiveness of our census effort used to locate nesting pairs, we used a handheld global positioning system (GPS, Garmin Map 12, Garmin Corporation, Olathe, KS) to record total distance, route traveled and total time spent searching each day using the GPS tracking function. Search tracks and nests were plotted on to USGS 1:24000 topographic maps.
We used broadcast digital recordings of both alarm and wail calls of accipiters and owls to identify active territories throughout the study area. Distance between calling stations varied from 150-300 m depending on openness of terrain.

Biases-Several potential biases are inherent in conducting a study to determine absolute abundance and density estimates, where such an effort assumes that each nest must be located. Our ability to locate each nesting pair was attributed to both the characteristics of the study area and to search effort. Our study area was relatively small (31 $\mathrm{km}^{2}$ ) and approximately $50 \%$ of this area was forested. The remaining portion was relatively open habitat and was conducive to direct observations of territorial birds.

Accurate recording of nest occupancy and reproductive success are sensitive to survey timing, duration, and researcher effort. Human disturbance can cause nest failure early in the breeding season and thus underestimate reproductive rates. Census efforts that begin late often miss pairs that failed early and, therefore, may overestimate reproductive rates. Researcher experience and their level of familiarity with the study area may also provide a source of potential error. However, two individuals (DC, RS) completed most of the nest census effort. One individual (DC) had over 40 years experience hiking on and adjacent to Blacktail Butte, and conducted raptor nest surveys during much of that time. RS has been intensively studying raptors on and adjacent to Blacktail Butte for the past 12 years.

Raptor census studies comparing both random and non-random sampling methods to estimate raptor abundance have shown practical difficulties or had potential biases for most species under study (see Lehman et al., 1998).

In conclusion, we believe that several factors combine to satisfy the requirements of an accurate nesting census on our study area: 1) relatively small and open study area that was conducive to direct observation of most raptors on the area, 2) the use of a GPS tracking technique that allowed us to daily map and detect areas in need of searching, and 3) trained and experienced field researchers.

Nesting success-Terminology used for reporting raptor-monitoring results follows recommendations made by Postupalski (1974). In 
our analyses of nesting success for buteos and ravens, we identified a nest to be occupied as those nests with fresh green material on the nest edge, and/or nesting areas where two adults were vocal and defensive when we walked into the nesting area. An alternate nest is referenced to be a nest structure with fresh greens that is located in close proximity to an occupied nest with birds present, but was not being currently used during the year of observation. In such instances we considered as occupied only one nest. Stick nests were inspected from the ground using binoculars, or with a modified mirror pole (Parker 1972). We located American kestrel nests by recording all sightings of adult kestrels during the spring and summer field season and returning to nests during the last two weeks of July when the adults were vocal and delivered food to the nestlings. We visited most nests a maximum of three times to determine occupancy and number of fledglings. We did not determine number of eggs and nestlings at all nests, therefore all productivity data reported are minimum values. We were unaware of any raptor pair that attempted a second clutch following a nest failure.

Prey density estimates - We estimating ground squirrel density within the study area by stationary visual counts in three colonies monitored since 2000 (see Chalfoun 2000, Beringia South, Unpubl. data). Ground squirrel colonies were identified and mapped in 2000 (Chalfoun 2000) with the intent of conducting long-term monitoring of ground squirrel population trends. In 2001, count data was collected from colonies $\mathrm{O} 2$ (2.32 ha) and S4 (1.27 ha) (see Chalfoun 2000 for details). Results of ground squirrel density estimates recorded in 2002 were compared to similar data collected in the two previous years.

\section{RESULTS}

Nest census and productivity-In 2002, we located 46 occupied raptor nests (Table 1). These 46 nests produced 43 young, an average of 1.0 young/nesting pair or 2.0 young/successful nest (Table 1). Of the total number fledged $(n=43)$, kestrels and ravens fledged 43 and $26 \%$, respectively (Fig. 2). American kestrels represented $40 \%$ of the total nesting population on the study area. We observed total nest failure for three species; Swainson's hawk $(n=4)$, Bald eagle $(n=1)$, and Longeared Owl $(n=1)$. Fledging dates for all species ranged from 5 June to 2 August.
Time of fledging was hard to quantify for American Kestrels and Osprey because Kestrels nested in tree cavities, and juvenile Osprey returned to the nest to roost for several weeks after fledging. Also, the large broods and asynchronous hatching typical of Common Ravens may have resulted in individuals of a brood fledging over a week or longer period. Excluding Kestrel nests, 17 of 28 (61\%) nest attempts failed, eight (28\%) did so before eggs hatched and $7(25 \%)$ between hatching and fledging. Cause of failure was seldom known but included a few cases where a large portion of the nest and nest lining material was pulled off to one side.

\begin{tabular}{|c|c|c|c|c|c|c|c|c|c|}
\hline Species & $\begin{array}{l}\text { No } \\
\text { Pair } \\
\text { s }\end{array}$ & $\begin{array}{l}\text { nesting } \\
\text { Pairs }\end{array}$ & $\begin{array}{c}\begin{array}{c}\text { No. sq. } \\
\text { miles } \\
\text { (km1/pair }\end{array}\end{array}$ & $\begin{array}{l}\text { Suce. } \\
\text { nests }\end{array}$ & $\begin{array}{l}\text { eggs } \\
\text { laid' }\end{array}$ & $\begin{array}{c}\text { eggs } \\
\text { hatched' }\end{array}$ & $\begin{array}{l}\text { young } \\
\text { thedge }\end{array}$ & $\begin{array}{l}\text { young } \\
\text { fledge } \\
\text { nesting } \\
\text { pair }\end{array}$ & $\begin{array}{c}\text { young } \\
\text { ledgel } \\
\text { suce nest }\end{array}$ \\
\hline $\begin{array}{l}\text { Red-tailed Hawk } \\
\text { Buteo iamnaicensis }\end{array}$ & 6 & 6 & $2.0(5.2)$ & 2 & 10 & 10 & 4 & 0.66 & 2.0 \\
\hline $\begin{array}{l}\text { Swainson's Hawk } \\
\text { Buteo swainsonii }\end{array}$ & 4 & 4 & $4(7.7)$ & 0 & 0 & 0 & 0 & 0 & 0 \\
\hline $\begin{array}{l}\text { American Kestrel } \\
\text { Falco sparverius }\end{array}$ & 18 & 18 & $0.66(1.7)$ & 10 & 20 & 20 & 20 & 1.1 & 2.0 \\
\hline $\begin{array}{l}\text { Sharp-shinned } \\
\text { Hawk } \\
\text { Accipiter striatus }\end{array}$ & 1 & 1 & $12(31.1)$ & 1 & 3 & 3 & 3 & 3.0 & 3.0 \\
\hline $\begin{array}{l}\text { Bald Eagie } \\
\text { H. letroccphinius }\end{array}$ & 1 & 1 & $12(31.1)$ & 0 & & & 0 & 0 & 0 \\
\hline Great horned Owl & 1 & 1 & $12(31.1)$ & 1 & 2 & 2 & 2 & 2.0 & 2.0 \\
\hline $\begin{array}{l}\text { Bubo virginianus } \\
\text { Long-ared Owl } \\
\text { dsio ottus }\end{array}$ & 1 & 1 & $12(31.1)$ & 0 & 5 & 0 & 0 & 0 & 0 \\
\hline $\begin{array}{l}\text { Osprey } \\
\text { Prndion halinetus }\end{array}$ & 1 & 1 & $12(31)$. & 1 & 2 & 2 & 2 & 2.0 & 2.0 \\
\hline $\begin{array}{l}\text { Common Raven } \\
\text { Cornus corrax }\end{array}$ & 13 & 13 & $0.9(2.4)$ & 6 & 44 & 30 & 12 & 0.9 & 2.0 \\
\hline Total & 46 & 46 & $\begin{array}{l}0.26 \\
(0.67)\end{array}$ & 21 & 86 & 65 & 43 & 1.0 & 2.0 \\
\hline
\end{tabular}

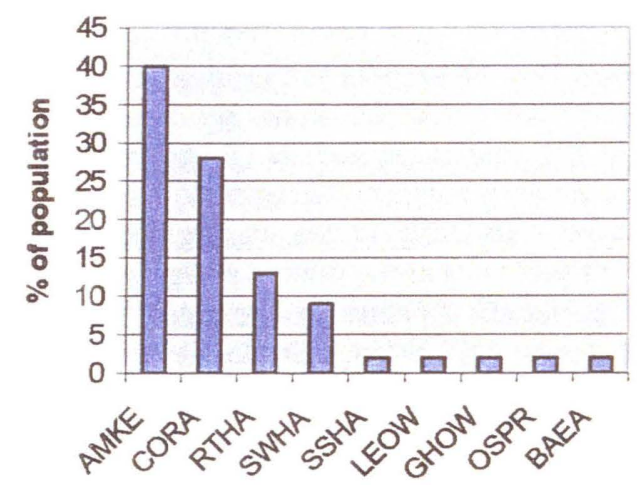

Figure 2. Percent total population of each species, GTNP, 2002. $N=46$

Nest-site preferences-Sixteen of $18(89 \%)$ kestrel nests were situated in or adjacent to open habitats, either in a narrow strip of cottonwoods such as along Ditch creek, or in a lone tree. One pair nested in a semi-open forest on the southwest side of Blacktail Butte. Kestrels nested in three tree species. Thirteen of $18(72 \%)$ kestrels nested in a live tree, however, each cavity was situated in a dead portion of that nest tree. We located one pair of kestrels in a nest box (Choinard). Kestrels fledged between 1 August and 6 August (mean $=$ August 3 ). 
Common ravens nested in four tree species and nests were generally located in isolated stands of trees, lone trees, or on edges of larger forest stands. Throughout the summer, we observed numerous ravens that were not nesting in the area. These were most likely unpaired birds, or pairs that nested outside our study area and used the study area to forage. Ravens fledged between 12 June and 26 June (mean=20 June).

Red-tailed hawks nested in three tree species and nests were located in habitats ranging from dense conifer stands on relatively steep hillsides, to a lone cottonwood tree situated in open sageflat/shrubland.

The Sharp-shinned hawk nest was found in a dense, mature spruce stand in the Snake River bottom. Accipiter nesting areas were located by identifying plucking posts and from adult vocalizations during May, and observing prey deliveries to the nest in July. The Bald eagle nest was situated adjacent to the Snake River in the southwestern portion of the study area.

We observed four individual raptors on the study area but did not locate nests, these included: Northern goshawk (Accipiter gentillus), Cooper's Hawk (Accipiter cooperii), Sharp-shinned hawk and (Accipiter striatus), and Great horned owl (Bubo virginianus). We observed a single adult goshawk on several different occasions along the Snake River bottom in the southwest portion of the study area from May through August. Throughout this area, we played taped calls early in the nesting season then switched to wail calls at the time of fledging. We did not hear goshawks respond to our taped calls. We observed a pair of Cooper's hawks in the western portion of the study area in late April and early May. One adult Sharp-shinned hawk was observed flying on several occasions along the forested portion of south Blacktail Butte. Two Great horned owl adults were also observed in the southwest portion of the study area in the dense cottonwood/spruce forest along the Snake River bottom. At least one adult Great horned Owl was observed multiple times on the north end of Blacktail Butte. It is possible that these individuals did not nest, nested just outside the study area and foraged on the study area, or, we failed to locate the nest.

Ground squirrel density-Ground squirrel density decreased in colony $\mathrm{O} 2$ from 48 squirrels/ha in 2002 to 20 squirrels/ha in 2001 , and decreased in colony S4 from 18 squirrels/ha in 2000 to nine squirrels/ha in 2001.

\section{$\uparrow \quad$ DISCUSSION}

Cause of reproductive variationComparison of raptor abundance, diversity and productivity in 2002 with data collected from 1947 showed a $77 \%$ increase (from 3 to 13 ) in the number of nesting ravens, a $50 \%$ decrease (from 12 to 6 ) in Red-tailed hawks, and a $90 \%$ decrease (from 10 to 1) in the number of nesting owls. We express caution when attempting to explain direct relationships in the long-term variability of raptor densities observed in our study area. Densities of raptors can fluctuate from year to year because of a number of factors, including quality and quantity of vegetation, weather conditions, food availability, and interspecific interactions (Newton 1979). In addition, some landscapes are in inherently harsh environments where some species may appear in low and variable abundance. During April, 12 of 14 days of precipitation was in the form of snow, and 23 days reached below $0^{\circ} \mathrm{C}$. During May, six of eight days of precipitation occurred as snow, 12 days were $<0^{\circ} \mathrm{C}$. In addition, weather conditions surrounding the mean hatching date for Red-tailed hawks consisted of four days of snow with below $0^{\circ} \mathrm{C}$ temperatures. Unusually cold and wet weather conditions can prevent the adults from feeding efficiently, and can result in a chilling of eggs or death of young nestlings (Newton 1986, Kostrzewa and Kostrzewa 1990).

We observed moderate to high infestations of blackflies (Simulium spp.) in nests of Red-tailed hawks and Common ravens, however, no nestling mortalities were attributed to blackflies (Smith et al. 1998).

Future research projects we recommend on raptors in order of feasibility based on available funding include: 1) community level habitat studies of diurnal and nocturnal raptors on the study area to determine niche partitioning and competitive interactions and potential effects of habitat changes on raptors, 2) analysis of foraging habitat by radiotracking adults of select members of each raptor guild on the study area, 3) radio-tracking study of adult and juvenile dispersal to identify habitats which the population uses for migration and over-wintering, and 4) future study designs could include coupling long-term measurements with manipulative experiments (e.g. experimental removal of ravens) that can help document patterns, determine mechanisms, and possibly generate new theories and testable hypotheses. 


\section{$\downarrow \quad$ ACKNOWLEDGEMENTS}

We wish to acknowledge the support and assistance of GTNP Wildlife Biologist Steve Cain. We especially thank Bryan Bedrosian and Emil McCain who surveyed many hundreds of acres in an enthusiastic manner.

\section{LITERATURE CITED}

Chalfoun, A. D. 2000. The distribution and abundance of Uinta ground squirrels, Spermaophilus armatus, in GTNP, Wyoming. Unpublished report, Beringia South.

Craighead, J. J., and F. C. Craighead. 1956. Hawks, Owls and Wildlife. Stackpole Co., Harrisburg, Pennsylvania, and Wildlife Management Inst., Washington, D.C. 443pp.

Craighead, F. C., and D. P. Mindell. 1981. Nesting raptors in western Wyoming, 1947 and 1975. J. Wildl. Manage. 45:865-872.

Craighead, F. L., F.C. Craighead Jr., and J.W. Tischendorf. 1987. Stability of raptor communities over time. Craighead Environmental Research Institute, Moose, Wy.

Dunk, J. R., R. N. Smith, and S. L. Cain. 1997. Nest-site selection and reproductive success in common ravens. Auk:116-120.

ESRI. 1996. Arcview, version 3.1. Environmental Systems Research Institute. Redlands, CA. USA.
Kostrzewa, A and R. Kostrzewa. 1990. The relationship of spring and summer weather with density and breeding performance of the buzzard Buteo buteo, goshawk Accipiter gentiles, and kestrel falco tinnunculus. Ibis 132:550-559.

Lehman, R. N., B. Carpenter, K. Steenhof, and M. N. Kochert. 1998. Assessing relative abundance and reproductive success of shrubsteppe raptors. J. Field Ornithology. 69:244-256.

Newton, I. 1979. Population ecology of Raptors. T \& A D Poyser. Calton, Eng. 399 p.

Newton, I. 1986. The sparrowhawk. T \& A D Poyser. Calton, Eng.

Parker, J. W. 1972. A mirror pole device for examining high nests. Bird-Banding. 43:216-218.

Postupalski, S. 1974. Raptor reproductive success: some problems with methods, criteria, and terminology. Pages 21-31 in Hamerstrom, F. N. Jr., Harrell, B. and Olendorff, R. eds. Management of raptors. Proc. of the Conf. on Raptor Conservation Techniques, Fort Collins, CO. Raptor Research Found. Vermillion, S. Dakota. 146pp.

Smith, R. S., S. L. Cain, S. H. Anderson, J. R. Dunk, and E. S. Williams. 1998. Blackfly-induced mortality of nestling Red-tailed Hawks. Auk. 115:368-375. 